\title{
GROUPING MULTIPLE INTELLIGENCES OF BIOLOGY STUDENTS USING HOWARD GARDNER'S MI MODEL AND TESTING ITS CORRELATION WITH THEIR PARENTS JOB
}

\author{
Relsas Yogica \\ Universitas Negeri Padang \\ Email: relsasyogica.1103992@gmail.com
}

\begin{abstract}
Multiple intelligences was developed by Howard Gardner's who focused their study in developmental learning of people. He had make a group contain 8 or 9 aspect, they are linguistic skill, music skill, logic-mathematic skill, spatial-visual skill, bodily-kinesthetic skill, intrapersonal skill, interpersonal skill, naturalis skill dan existency skill. Last two aspect just added. Based on learning theory, these skills that students has, are influented by their own family. In this research, only 7 aspects that was groupped and its tested to find a correlation between multiple intelligences and the family. The "family" in this case mean what kind of mother's job. These research samples are 44 students from Biology Department, Mathematic and Natural Science Faculty, Universitas Negeri Padang. Sampling method was purposive sampling. Data was collected by using questionaire. There are no repetition in data collection process. The result shows that parent's job does not make significant effect to influent student intelligences. This conclusion was made by using Spearman Correlation Formula,.
\end{abstract}

Keywords: Multiple Intelligences, Howard Gardner's MI Model 


\section{Introduction}

Multiple intelligence is a intelligence theory that was developed by Howard Gardner, a Harvard University psychological expert. Morgan (2010) said that multiple intelligences that were mentioned by Gardner is separated into seven independently intelligences. They are linguistic intelligences, logical-mathematic intelligences, musical intelligences, bodilykinesthetic intelligences, spatial-visual intelligences, interpersonal intelligences, and intrapersonal intelligences. But, they do not a brand new style of intelligence, just to make reframe from older style, cognitive style.

Understanding about multiple intelligences of one person must gives positive effect to their own developmental learning. For example, the condition like some one can influent some other easily is learning process. Teacher share subject material to their students aims to create a new sense in student's learning experience and also to reach spesific learning objective. Here, we should know that multiple intelligences can be a guide to develop learning objectives (Delgado, 2015).

A learning procees based on multiple intelligences must gives a positive impact that learning by using conventional method (Sheahan et. al, 2015). For example, in reading course, students in multiple intelligence based class faster and greater to read than other conventional class (AlBalhan, 2006).

Multiple intelligences can shows in each individual students by influence of internal factor, such as gender and external factor, such as parents. The research of Emmiyati et. al. (2014) resulted that female has musical intelligence, interpersonal intelligence dan existential intelligence stronger than male. External factor in this case is parent's job, for example. We define parents in this research as a mother, because mother with assumed has biggest role in their own kid. Nor (2008) said school will going better if mothers of the students take their position in plan, do and evaluation of school programmes.

Because of the explanation about how important to know multiple intelligences and how important to understand what factor can influent them, so this research will answer all of the question about. The hypothesis of this research is "there is significant inluence parent's job to multiple intelligences of college students in Biology Department, Universitas Negeri Padang.

\section{Method}

This is a experimental-descriptive research by using questionnaire to collect data from 44 research subjects. The questionnaire was created by Howard Gardner to detect multiple intelligences and to know what intellience is dominant than other. Correlation between parent's job and multiple intelliegences of students were calculated by Spearman formula (Sundayana, 2014).

Subject was grouped into 4 groups based on their mother's job. They are Number 1 (housewife), Number 2 (farmer), Number 3 (entrepreneur) and Number 4 (civil servant).

\section{Result and Discussion}

The data analysis shows no body in the each group has logical-mathematic intelligences as dominant intelligence. To konow more about the research' result, look at the pictures below. 


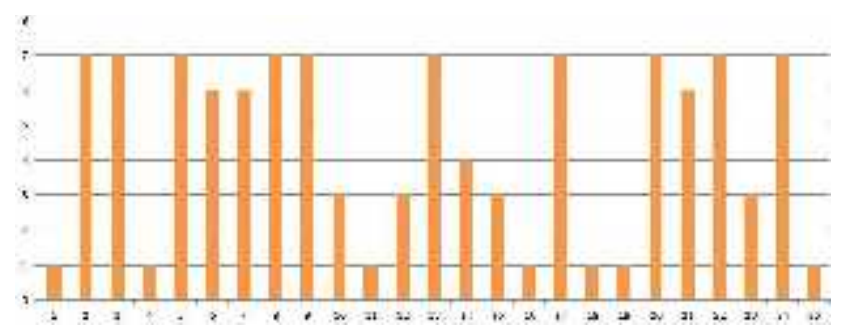

Figure 1. MI's from Housewife family

That picture shows us that there are 25 people in this group. Only one people have bodilykinesthetic intelligence as a dominant intelligence, in fewest number. The highest number is 10 people in intrapersonal intelligence. There is no body in this gorup that has logical-mathematic and spatial-visual intelligence.

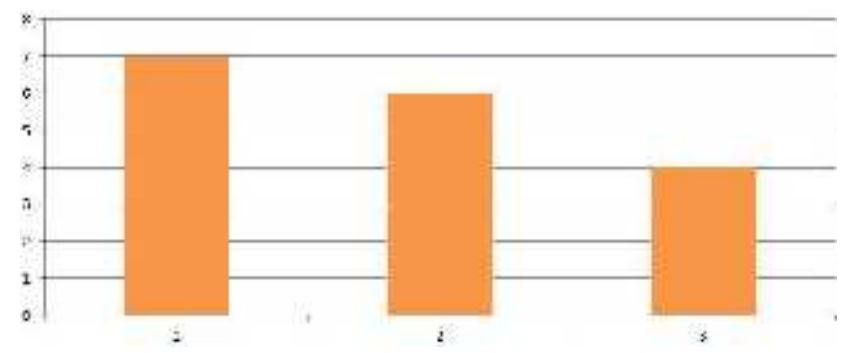

Figure 2. MI's from Farmer family

Picture 2 shows that only three person from farmer family. They have dominant intelligence in intrapersonal, interpersonal dan bodily-kinesthetic.

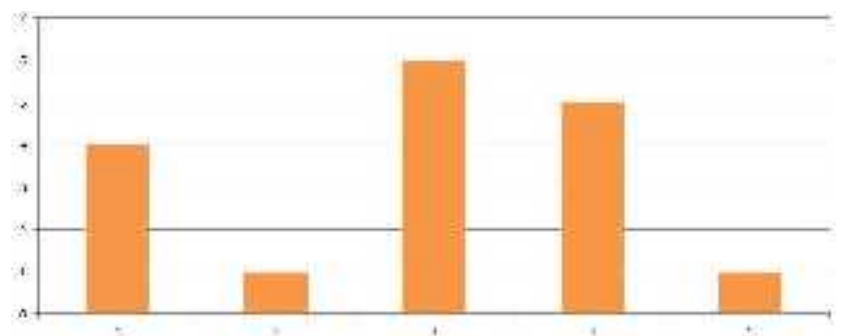

Figure 3. MI's from Entrepreneur family

That picture has data from students that their mothers are entrepreneur. From 5 people in this group, two of them have linguistic intelligence, and other has bodily kinesthetic, spatial visual and interpersonal intelligences.

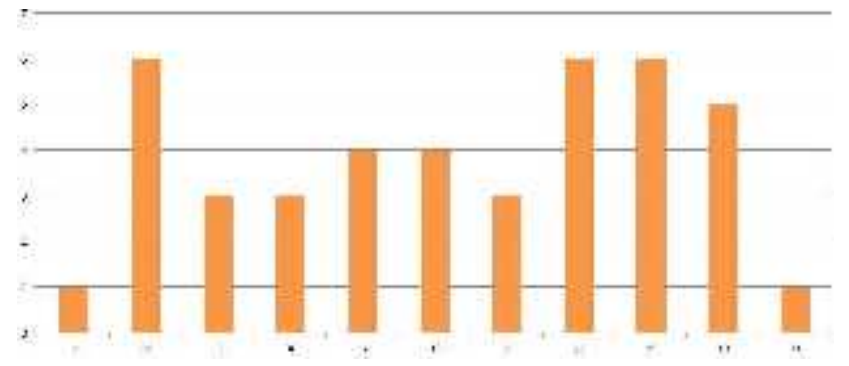




\section{Figure 4. MI's from Civil Servant family}

Last picture containts data from civil cervant family. There are 11 people in this group with linguistic intelligence (two people), musical intelligence (three people), bodily-kinesthetic (two people), spatial-visual intelligence (one person), and interpersonal intelligence (three people).

Overall, the data distribute normally, but no one in this research subjects have logicalmathematic intelligences as a dominant intelligence. I assume about this result that students in Biology Department did not choose others because they weak in logical-mathematic. Then, if this research continue with students from Mathematic Department or somekind like this, so research result will show people with logical-mathematic intelligence as dominant intelligence.

After mapping phase has done, I continue to test correlation coefficient by using Spearman formula. Result was 1,3299 as $t_{\text {value }}$ then compare to $t_{\text {table }}(2,0211)$, so $t_{\text {value }}<t_{\text {table. For }}$ a conclusion in this research, because of correlation coefficient did not significant so its mean there are no significant influence of parent's job with student's multiple intelligence in Biology Departmen of Universitas Negeri Padang. Research hypothesis is rejected.

Hypothesis is a conclusion from observation data from many source, but it still does not correct $100 \%$. So, it should be tested by experimental method. In this research, hypothesis is rejected, means parent's job (mother's job) did not give any significant impact to their childreen (college students in Biology Department of Universitas Negeri Padang). This condition is possible because subjects has reach teenage phase of live. They are not only contact with their parent, but also their own environtment, such as their friend. Dominant intelligence on their own does not impact by parents anymore, but also environtmental factors at once.

\section{Acknowledgement}

Thanks to all friends in my department and a lot thanks to all students in Biology Department of Universitas Negeri Padang.

\section{References}

Al-Balhan, Elsa M., Multiple Intelligence Styles in Relation to Improved Academic Performance in Kuwaiti Middle School Reading, Digest of Middle East Studies, 15(1), 18-34, Spring 2006.

Delgado, May T, Multiple Intelligences and Vocabulary Levels of The Teachers Education Students: Bases for Instructional Materials Development, International Journal of Multidisciplinary Research, 3(1), 2015.

Emmiyati et. al., Multiple Intelligences Profiles of Junior Secondary School Students in Indonesia, International Education Studies, 7(11), 103-110, November 2014.

Morgan, Harry, An Analysis of Gardner's Theory of Multiple Intelligence, Roeper Review, 18(4), January 2010.

Nor, Mohammad, Teacher's Perception Towards Parental Involvment in Their Children's Education in The Secondary Schools, Temerloh, Malaysia, Universiti Putra Malaysia Institutional Repository, May 2013.

Sheahan, Linda et. al., An Exploratory Trial Exploring The Use Of a Multiple Intelligences Teaching Approach (MITA) for Teaching Clinical Skills to First Year Undergraduate Nursing Students, Nurse Education Today, 35(12),1148-1154, December 2015. 
Sundayana, Rostina, Statistika Penelitian Pendidikan, Alfabeta, Bandung. 